\title{
Co-movement of commodity price indexes and energy price index: a wavelet coherence approach
}

\author{
Dervis Kirikkaleli ${ }^{* *}$ (D) and Hasan Güngör ${ }^{2}$
}

*Correspondence:
dkirikkaleli@eul.edu.tr
${ }^{1}$ Department
of Banking and Finance,
Faculty of Economic
and Administrative Sciences,
European University of Lefke,
Lefke, Northern Cyprus,
TR-10, Mersin, Turkey
Full list of author information
is available at the end of the
article

*Correspondence: dkirikkaleli@eul.edu.tr 1 Department Faculty of Economic and Administrative Sciences, European University of Lefke article

\begin{abstract}
This research sheds light on the causal link between commodity price indexes, i.e., the Agricultural Raw Materials Price Index, Industry Input Price Index, Metal Price Index, and Energy Price Index, in the global market, using wavelet coherence, Toda-Yamamoto causality, and gradual shift causality tests over the period 1992M1 to $2019 \mathrm{M} 12$. Findings from the wavelet power spectrum and partial wavelet coherence reveal that: (1) there was significant volatility in the Agricultural Raw Materials Price Index, Industry Input Price Index, Metal Price Index, and Energy Price Index between 2004 and 2014 at different frequencies; and (2) commodity price indexes significantly caused the energy price index at different time periods and frequencies. It is noteworthy that the outcomes of the Toda-Yamamoto causality and gradual-shift causality tests are in line with the results of wavelet coherence.
\end{abstract}

Keywords: Energy price, Commodity price, Wavelet coherence, Causality

JEL Classification: Q4, Q2, E3, C3

\section{Introduction}

Commodities play a key role in global trade, connecting nations around the world. The trade of an item is affected by numerous factors, which have been studied from various perspectives. It can be challenging when the prices of commodities fluctuate in the markets, making it difficult to sustain the smooth flow of trade. Globalization has contributed to the interconnections of prices among many items, whose trade has become easier through globalization. Over the last century, commodities have become popular tools of investment portfolios. For example, while corn is an agricultural commodity and food, it is also a source of ethanol, and thus biodiesel, which is a commodity in the energy market, and it is an investment tool for speculators in financial markets. The lack of a thorough understanding of the relationships between commodities and their prices bring challenges to producers, traders, investors, and policy-makers when making decisions. If the price of a commodity has a causal relationship with the price of another, then it is possible to predict price fluctuations in the other. This is important since it can author(s) and the source, provide a link to the Creative Commons licence, and indicate if changes were made. The images or other third party material in this article are included in the article's Creative Commons licence, unless indicated otherwise in a credit line to the material. If material is not included in the article's Creative Commons licence and your intended use is not permitted by statutory regulation or exceeds the permitted use, you will need to obtain permission directly from the copyright holder. To view a copy of this licence, visit http:// creativecommons.org/licenses/by/4.0/. 
enable more accurate planning and smoother operations in the management of supply and demand in a global context.

Scholars have shown substantial interest recently in the price relationships between energy commodities and various non-energy commodities. This is due to the clear comovement of oil and food prices during the global financial crisis from 2006 to 2008. It is important to understand the price movements since they contain useful information, and in some cases are transmitted to other prices. This can be viewed as a contagious process whose effects are transferred from one market to another. To make predictions in different markets, participants and regulators need to understand how the influence of one market transmits to another via different channels. For example, speculators would want to know about price movements and their connections in order to speculate in futures markets for risk management, hedging strategies, and asset pricing (Kou et al. 2014, 2020; Chao et al. 2020), while traders would want to know the nexus between prices of certain commodities so that they can predict their price movements. Although it sounds appealing, to merely consider the physical links between commodities is not sufficient to forecast price movements in the markets, as there may be some nonlinearity issues.

Our approach differs from those of other researchers in two ways. First, we use a different method to examine the co-movement of energy and non-energy commodity prices. The wavelet coherence method is rarely used in this field, and it has some advantages over other methods. Pal and Mitra (2017) discussed these advantages and argued that they originate from statistical physics and combine information about both time and frequency. This method uniquely allows the decomposition of unidimensional time data into the bidimensional time-frequency sphere. Second, the data we use represent the global price indexes and have not been extensively used in such analysis.

A vast amount of empirical literature exists on co-movement, particularly between oil and food (agricultural commodity) prices in many markets. As oil is the commodity most commonly used as an energy source, it has linkages to almost all other commodities through energy costs, and thus production costs. Therefore, oil prices have a spillover effect on many other commodities. This increases the importance of oil prices in the global economy, such as through production costs, domestic inflation, and exchange rates. The findings of this particular strand of the literature are mixed. While some researchers have found evidence of co-movement between oil and commodity prices, others have supported the neutrality hypothesis of no relationship. For example, Zhang and Reed (2008) studied the causal effect of world oil prices on the Chinese agricultural commodity market and found no evidence that oil prices co-moved with some agricultural commodity prices in China over the period of the study. Esmaeili and Shokoohi (2011) analysed the co-movement of the food price index with the macroeconomic and oil price indexes, and reported that the oil price index has an influence on the food price index, whereas the macroeconomic index has an influence on the food price index. Nazlioglu and Soytaş (2011) studied the oil-agricultural commodity relationship, concentrating on nonlinear causality, and found nonlinear feedbacks between oil and agricultural commodity prices, while there was a persistent unidirectional nonlinear causality from oil to certain agricultural commodities. However, their causality analysis, similar to those of Yu et al. (2006), Nazlioglu and Soytaş (2011), and Reboredo 
(2012), among others, supported the neutrality hypothesis. In other words, agricultural commodity prices are neutral to the effects of oil price movements in the long run. In another study, Nazlioglu et al. (2013) considered the volatility transmission between oil and selected agricultural commodity prices using a sample divided into pre-and post-crisis periods (before and after 2006-2008). They found no risk transmission during the pre-crisis period, whereas the dynamics of volatility changed significantly during the post-crisis period, and risk transmission emerged as a new dimension of their relationship. Similar to Nazloglu et al. (2013), Wang et al. (2014) reported that in the pre-crisis period, oil shocks could explain the minor changes in agricultural commodity prices. However, both during and after the crisis, the explanatory ability of oil prices on agricultural commodity prices was much higher. They argued that in the pre-crisis period, most of the variation in agricultural prices came from the demand side. Avalos (2014) argued that after the Energy Policy Act of 2015 was implemented in the US, oil prices become a relevant factor in certain agricultural commodity markets such as corn. This is due to the use of corn-based ethanol as a biofuel, which creates a physical link between the oil and agricultural commodity markets. Thus he found a two-way feedback relationship between the prices of oil and agricultural commodities. Koirala et al. (2015) stated that biodiesel, diesel, corn oil, and gasoline prices affect energy producers. As also explained by Avalos (2014), to link agricultural commodities to oil by regulation allowing the use of ethanol as biodiesel is expected to create a causal link between the prices of commodities and oil. Ultimately, they found that agricultural futures, commodity prices, and energy futures prices are highly correlated and show a significant relationship. Hence they concluded that an increase in energy prices increases agricultural commodity prices. Kapusuzoğlu and Ulusoy (2015) studied the effect of Europe Brent and West Texas Intermediate oil prices on selected agricultural commodity prices and discovered a unidirectional causality running from oil prices to agricultural commodity prices. Lucotte (2016) also studied the co-movement of oil and agricultural commodity prices for a sample consisting of two periods, pre- and post-crisis, and found strong evidence that in the post-crisis period, there was a strong positive co-movement between crude oil and agricultural commodity prices. De Nicola et al. (2016) conducted a comprehensive study on the price returns of energy and agricultural commodities and found a strong correlation between them. Furthermore, they revealed that the co-movement among the commodities increases with the use of biofuels. Fowowe (2016) studied the links between oil and agricultural commodity prices for South Africa. He found no relationship between them, and therefore his findings supported the neutrality hypothesis. Pal and Mitra (2017) studied the co-movements of crude oil prices and the world food price index. Their findings supported the view that oil prices co-move with food prices and are also led by oil prices.

Other researchers have analysed the links between oil prices, food prices (agricultural commodity prices), and exchange rates, as there is a channel through which oil prices transmit to local agricultural markets via exchange rates. Nazlioglu and Soytas (2012) studied world oil prices and agricultural commodity prices, accounting for changes in the relative strength of the US dollar. They found evidence of the impact of world oil price changes on agricultural commodity prices. Furthermore, their findings confirmed the positive impact of a weak dollar on agricultural commodity prices. 
Scholars have also researched the nexus between oil prices, food prices, metal prices, and exchange rates. Industrial metal prices are important in developed and developing economies since they represent one of the main inputs of industrial production. Precious metals such as gold, silver, platinum, and palladium are used as investment and hedging tools for international investors, as do currencies. Because of international trading of these commodities, exchange rates play a key role, since most world trade is priced in US dollars or euros. The exchange rate is one of the main channels through which the international price volatilities of commodities are transmitted to local economies. Using monthly data for the period 1973-1996, Chaudhuri (2001) reported that real commodity prices and real oil prices are co-integrated. His findings revealed that oil is used as an intermediate commodity in the production of agricultural commodities and metals and that the rise in oil prices has an impact on the real prices of other commodities via the real exchange channel. Sari et al. (2010) studied the relationship between the spot prices of some precious metals, oil prices, and the US dollar/euro exchange rate. They found a weak long-run equilibrium relationship but strong feedback in the short run, indicating that those commodities may not be sensitive to common economic factors in the long run, and investors may benefit from diversification into precious metals. Furthermore, exporters can benefit from weak long-run relationships by shifting their exports into other precious metals, thus diversifying the price fluctuation risk of the future. Ji and Fan (2012) argued that the link between the crude oil market and the agriculture and metal markets has increased. They studied the pre-and post-2008 periods and found that the overall level of correlation strengthened in the latter. The crude oil market showed significant volatility spillover effects on non-energy markets. Their findings also revealed that the influence of the US dollar on commodity markets weakened in the post-crisis period. Jain and Ghosh (2013) studied the post-crisis period for India. They researched the link between global oil prices, precious metal prices, and the rupee/US dollar exchange rate. Their findings showed that the global oil prices transmitted to the Indian economy via the exchange rate channel since India is an importer of both precious metals and oil. Wang and Chueh (2013) studied the US dollar interest rates, US dollar, and oil and gold prices. Their data covered the period between 1989 and 2007. Therefore, the research focused largely on the pre-crisis period of 2006-2008. Their findings revealed that interest rates had a positive influence on future crude oil prices and a negative influence on future gold prices. Also, gold and oil prices positively influenced each other. In the long run, a relationship exists whereby interest rates influence the US dollar, which in turn influences international crude oil prices. Furthermore, there is a price transmission relationship from interest rates to gold prices, which is an important insight for speculators. Mensi et al. (2013) investigated the return links between volatility transmission between the S\&P 500 and commodity price indexes for energy, food, gold, and beverages for the period between 2000 and 2011. Their findings showed significant transmission among the S\&P 500 and commodity markets in terms of return and volatility spillover. Klotz et al. (2014) studied the case of China and found a causality running from economic activity to energy and industrial metal prices. Their findings further revealed that energy and industrial metal prices respond positively to interest rates in China. When the exchange rate system is relaxed, industrial metal prices tend to be higher. Balcilar et al. (2015) researched the transmission dynamics between oil spot prices, precious 
metals spot prices, and the US dollar/euro exchange rate for the period 1987-2012. They considered high- and low-volatility regimes and found that silver and oil were the most volatile, while gold was considered a safe haven for investors. Gold prices were found to be the most informative among all the assets, while palladium prices had a negative impact on the exchange rate. Rafiq and Bloch (2016) studied commodity and oil prices using nonlinear models, using data from 1900 to 2011. They found a long-run relationship using both linear and nonlinear models. Oil prices were found to have a low impact on most agricultural commodity prices, but a substantial impact on metal prices. Kang et al. (2017) studied the dynamics of return and volatility spillover indexes to reveal the intensity and direction of transmission during the 2006-2008 global financial and European sovereign debt crises, focusing on crude oil, precious metals, and agricultural commodity futures markets. Their findings showed that during the crises, the correlation between the commodities' futures market returns increased sharply. During the crisis period, the benefits of international portfolio diversification diminished for investors. Furthermore, there was a strong volatility spillover across commodity futures markets. Gold and silver were found to be information transmitters, while others were receivers. Karabulut et al. (2020) explored the linkage between commodity prices and world trade uncertainty using a wavelet coherence approach. They found a positive correlation between commodity prices and world trade uncertainty.

The impact of the 2006-2008 oil price shocks on local economies has also been studied (Farzanegan and Markwardt 2009; Tang et al. 2010; Cunado and de Gracia 2015; Coronado and Rojas 2016; Morana 2017; Alekhina and Yoshino 2019). The transmission channels of oil price shock are: (a) supply-side shock effect due to increases in production costs by oil price shock; (b) wealth transfer effect due to the marginal consumption rate of petrodollars and that of ordinary trade surplus; (c) inflation effect due to increased inflation rates from increased oil prices; (d) real balance effect due to changes in money demand and monetary policy due to increased oil prices; (e) sector adjustment effect due to the adjustment cost of industrial structure from increased oil prices; and (f) uncertainty over the oil price and its impact on local economies (Tang et al. 2010). Findings were mixed.

This study investigates the causal link between the commodity price indexes, namely Agricultural Raw Materials Price Index, Industry Input Price Index, Metal Price Index, and Energy Price Index for the global market. We employ the Toda-Yamamoto causality, Fourier Toda-Yamamoto causality, and wavelet coherence tests to answer the following questions: (1) Is there any causal link between the commodity price indexes and the energy price index? (2) If yes, in which direction(s)?

\section{Data}

Because the main aim, as well as the innovation of the present study, is to investigate the time-frequency dependency between commodity price indexes-namely, the Agricultural Raw Materials Price Index, Industry Input Price Index, Metal Price Index, and Energy Price Index-in the global market using wavelet power spectrum and partial wavelet coherence approaches, a unique dataset is used, which was obtained from the International Monetary Fund (IMF), covering the period 1992M1 to 2019M12. 
Table 1 Descriptive statistics

\begin{tabular}{lllll}
\hline Variable & Energy price index & $\begin{array}{l}\text { Agriculture raw } \\
\text { material index }\end{array}$ & $\begin{array}{l}\text { Industry input } \\
\text { price index }\end{array}$ & Metal price index \\
\hline Code & EPI & API & IPI & MPI \\
Source & IMF & IMF & IMF & IMF \\
Time & $1992 \mathrm{M} 1-2019 \mathrm{M} 12$ & & & \\
Mean & 118.128 & 86.927 & 97.386 & 80.230 \\
Median & 109.485 & 80.361 & 87.977 & 70.182 \\
Maximum & 312.413 & 140.146 & 221.183 & 179.729 \\
Minimum & 30.923 & 56.496 & 43.777 & 30.420 \\
Std. Dev & 67.951 & 21.519 & 43.940 & 44.440 \\
Skewness & 0.5831 & 0.419 & 0.575 & 0.410 \\
Kurtosis & 2.232 & 2.002 & 2.264 & 1.775 \\
Jarque-Bera & 27.283 & 23.766 & 26.113 & 30.441 \\
Probability & 0.000 & 0.000 & 0.000 & 0.000 \\
\hline
\end{tabular}

Energy Price Index is constructed by the Crude oil (petroleum), Natural Gas, Coal Price and Propane Indices while the Metal Price Index is constructed by the Metal Price Index (Base Metals) and Precious Metals Index. However, the Industry Input Price is constructed by the Index Agricultural Raw Materials and Base Metals Price Indices, while the Agriculture Price Index is constructed by the Food and Beverages and Agriculture Raw Materials Price Indices

The descriptive statistics of the time series variables and their codes are presented in Table 1. The pattern of the time series variables is illustrated in Fig. 1.

\section{Methodology}

In this study, the DF-GLS, KPSS, and Z-A unit root tests are employed to explore the order of integration of the Agricultural Raw Materials Price Index, Industry Input Price Index, Metal Price Index, and Energy Price Index. Also applied is the more recent unit root test of Cavaliere et al. (2011), which "allows for a possible structural break and non-stationary volatility, where the volatility includes both single and multiple abrupt breaks in variance, polynomially trending volatility, piecewise trending volatility, and smooth transition variance breaks" (Ghoshray 2019).

Consistent with the main aim of the study, the partial wavelet coherence approach is used to capture the co-movement commodity price indexes and Energy Price Index. The wavelet coherence approach was initially developed by Goupillaud et al. (1984). This allows the decomposition of one-dimensional time data into the bi-dimensional time-frequency sphere (Grinsted et al. 2004; Adebayo and Odugbesan 2020; Adebayo and Beton Kalmaz 2020; Kirikkaleli 2021), and therefore facilitates the investigation of the long- and short-term causal linkage between commodity price indexes and the Energy Price Index. In other words, a multi-scale decomposition technique creates a natural framework to illustrate frequency-dependent behaviour to explore the linkage between the commodity price indexes and the Energy Price Index. The wavelet $(\psi)$ used in this paper is part of the Morlet wavelet family. It has the equation $\psi(t)=\pi^{-\frac{1}{4}} e^{-i \omega_{0} t} e^{-\frac{1}{2} t^{2}}, p(t), t=1,2,3 \ldots, T$, where $\psi$ is applied on narrow observations.

As discussed by Kirikkaleli (2019) and Adebayo (2020), time (represented by k) and frequency (represented by f) are the main two elements of the wavelet approach. "The k parameter has an important role in detecting the exact location of a wavelet by 
relocating the wavelet over time, while f monitors the distended wavelet for localizing different frequencies" (Orhan et al. 2019). The transformation of the wavelet $\psi$ equation with $\mathrm{k}$ and $\mathrm{f}$ elements is shown as

$$
\psi_{k, f}(t)=\frac{1}{\sqrt{h}} \psi\left(\frac{t-k}{f}\right), k, f \in \mathbb{R}, \quad f \neq 0 .
$$

The continuous wavelet transformation, which can be obtained from $\psi$ as a function of $k$ and $f$, is

$$
W_{p}(k, f)=\int_{-\infty}^{\infty} p(t) \frac{1}{\sqrt{f}} \psi\left(\overline{\frac{t-k}{f}}\right) d t
$$

Equation 2 with time series $\mathrm{p}(\mathrm{t})$ and coefficient $\psi$ can be written as

$$
p(t)=\frac{1}{C_{\psi}} \int_{0}^{\infty}\left[\int_{-\infty}^{\infty}\left|W_{p}(a, b)\right|^{2} d a\right] \frac{d b}{b^{2}} .
$$

To obtain information about the behaviour of the time series, we used the wavelet power spectrum (WPS) in the present paper,

$$
\operatorname{WPS}_{p}(k, f)=\left|W_{p}(k, f)\right|^{2} .
$$

As stated by Kirikkaleli and Gokmenoglu (2019), Alola and Kirikkaleli (2020) and Zhang, et al. (2021) unlike traditional causality tests, the wavelet approach combines time and frequency approaches in order to investigate the link between the time series $\mathrm{p}(\mathrm{t})$ and $\mathrm{q}(\mathrm{t})$. The cross-wavelet transform (CWT) of the time series is

$$
W_{p q}(k, f)=W_{p}(k, f) W_{q}(\bar{k}, f),
$$

and the squared wavelet coherence of $W_{p q}(k, f)$ is

$$
R^{2}(k, f)=\frac{\left|C\left(f^{-1} W_{p q}(k, f)\right)\right|^{2}}{C\left(f^{-1}\left|W_{p}(k, f)\right|^{2}\right) C\left(f^{-1}\left|W_{q}(k, f)\right|^{2}\right)},
$$

where $c$ represents the smoothing process over time, with $0 \leq R^{2}(k, f) \leq 1$. When the value of $R^{2}(k, f)$ approaches 0 , it shows no correlation between $p(t)$ and $q(t)$, and this is indicated in blue. When the value of $R^{2}(k, f)$ approaches 1 , meaning that $p(t)$ and $q(t)$ are correlated, it is shown in red and surrounded by a black line in the wavelet figures.

However, $\mathrm{R}^{2}(\mathrm{k}, \mathrm{f})$ does not allow us to distinguish between positive and negative correlation. Torrence and Compo (1998) proposed a tool to explore the wavelet coherence via deferment indicators in the fluctuation of two-time series. We can distinguish positive and negative correlation by Kirikkaleli (2020)

$$
\phi_{p q}(k, f)=\tan ^{-1}\left(\frac{\mathrm{L}\left\{\mathrm{C}\left(\mathrm{f}^{-1} \mathrm{~W}_{\mathrm{pq}}(\mathrm{k}, \mathrm{f})\right)\right\}}{O\left\{C\left(f^{-1} W_{p q}(k, f)\right)\right\}}\right),
$$

where $\mathrm{L}$ indicates an imaginary operator, and $O$ is a real-part operator. 
In this research, a scale of 64 is determined since the data cover the period of 1992M1 to 2019M12 (336 observations). The white cone-shaped curve represents the cone of influence in the figures of WPS, demonstrating an edge below which the wavelet power is affected because of discontinuity, while the thick black shape indicates a $5 \%$ significance level determined by Monte Carlo simulations. In the figures of wavelet coherence, while the colder coloured areas denote low dependency among the time series variables, the warmer coloured areas report high dependency. The direction of significant causality or correlation is represented by arrows surrounded by a thick black line in the figures of wavelet coherence. In the figures, the positive and negative correlation among the time series variables are represented by arrows pointing to the right and left, respectively (Torrence and Compo 1998; Kristoufek 2015; Demir et al. 2020; Alola and Kirikkaleli 2020). Arrows pointing up, right-up, or left-down denote that the second variable causes the first variable, while arrows pointing down, right-down, or left-up indicate that the first variable causes the second variable.

In addition to the wavelet coherence approach, the Toda and Yamamoto causality and gradual shift causality approaches are applied to capture the causal linkage between commodity price indexes, i.e., the Agricultural Raw Materials Price Index, Industry Input Price Index, Metal Price Index, and Energy Price Index, in the global market. Unlike the Granger causality test (Granger 1969), the Toda-Yamamoto causality test allows us to conduct vector autoregressive (VAR) estimation in levels, regardless of whether the series has the same order of integration (d). Therefore, because taking the difference of the time series data is avoided, no information will be lost. Moreover, the Toda-Yamamoto causality test can be employed if the time series variables are not cointegrated. In this test, while investigating the causal linkage between the Energy Price Index and Agricultural Raw Materials Price Index, and the Industry Input Price Index and Metal Price Index, we eliminate the pre-test bias problem by using the procedures of the Toda -Yamamoto causality test, whose standard equation is

$$
\mathrm{y}_{\mathrm{t}}=a+b_{1} \mathrm{y}_{\mathrm{t}-1}+\cdots+b_{\mathrm{p}} \mathrm{y}_{\mathrm{t}-\mathrm{p}}+\cdots+b \mathrm{p}+{ }_{\mathrm{d}} \mathrm{y}_{\mathrm{t}-(\mathrm{p}+\mathrm{d})}+\mathrm{e}_{\mathrm{t}},
$$

where $y_{t}$ is a vector of $k$ variables, $a$ is a vector of intercepts, $e_{t}$ is a vector of residual terms, and $b$ is a matrix of parameters.

Nazlioglu et al. (2016) recently developed a gradual shift causality test, which is also called the Fourier Toda-Yamamoto causality test. This allows us to account for both gradual and smooth structural shifts in a causality analysis. By enabling the application of a small number of low-frequency components, the Fourier approximation methodology does not require the properties of the structural breaks to be known. Hence the test overcomes the problems associated with an unknown number of structural breaks and occurrence dates that are inherent to conventional causality tests. We also employ this approach to check the causal linkage between all four commodity price indexes, i.e., the Agricultural Raw Materials Price Index, Industry Input Price Index, Metal Price Index, and Energy Price Index.

\section{Empirical findings}

As a first step, we employ the DF-GLS, KPSS, and Z-A unit root tests to capture the order of integration of the Energy Price Index (EPI), Agricultural Raw Materials Price 
Table 2 Unit root tests

\begin{tabular}{|c|c|c|c|c|c|c|}
\hline \multirow[t]{2}{*}{ Variables } & DF-GLS & KPSS & Z-A & DF-GLS & KPSS & Z-A \\
\hline & \multicolumn{3}{|c|}{ Panel A: Unit-root tests in levels } & \multicolumn{3}{|c|}{$\begin{array}{l}\text { Panel B: Unit-root test in first } \\
\text { differences }\end{array}$} \\
\hline \multicolumn{7}{|c|}{ Including constant } \\
\hline EPI & -1.329 & $1.531^{* * *}$ & $-3.512(2013 \mathrm{M} 08)^{* * *}$ & $-10.821^{* * *}$ & 0.009 & $\begin{array}{l}11.202^{* * *} \\
(2008 \mathrm{M} 08)^{* *}\end{array}$ \\
\hline API & -1.317 & $0.816^{* * *}$ & $\begin{array}{l}-4.288 \\
(2009 \mathrm{M} 11)^{* * *}\end{array}$ & $-13.197^{* * *}$ & 0.056 & $\begin{array}{l}-9.695^{* * *} \\
(2011 \mathrm{M} 05)^{* * *}\end{array}$ \\
\hline IPI & -912 & $1.432^{* * *}$ & $\begin{array}{l}-3.461 \\
(2005 \mathrm{M} 08)^{* * *}\end{array}$ & $-11.698^{* * *}$ & 0.082 & $\begin{array}{l}-12.457^{* * *} \\
(2011 \mathrm{M} 03)^{* * *}\end{array}$ \\
\hline MPI & -0.885 & $1.484^{* * *}$ & $\begin{array}{l}-3.252 \\
(2005 \mathrm{M} 08)^{* * *}\end{array}$ & $-12.156^{* * *}$ & 0.095 & $\begin{array}{l}-13.174^{* * *} \\
(2011 \mathrm{M} 03)^{* * *}\end{array}$ \\
\hline \multicolumn{7}{|c|}{ Including constant and trend } \\
\hline EPI & -2.388 & $0.184^{* * *}$ & $\begin{array}{l}-4.534 \\
(2010 \mathrm{M} 10)^{* * *}\end{array}$ & $-10.771^{* * *}$ & 0.070 & $\begin{array}{l}-11.183^{* * *} \\
(2008 \mathrm{M} 08)^{* *}\end{array}$ \\
\hline API & -2.388 & $0.208^{* *}$ & $\begin{array}{l}-4.762 \\
(2009 \mathrm{M} 11)^{* * *}\end{array}$ & $-13.133^{* * *}$ & 0.048 & $\begin{array}{l}-9.780^{* * *} \\
(2009 \mathrm{M} 04)^{* *}\end{array}$ \\
\hline IPI & -1.993 & $0.186^{* *}$ & $\begin{array}{l}-3.848 \\
(2009 \mathrm{M} 04)^{* * *}\end{array}$ & $-11.917^{* * *}$ & 0.071 & $\begin{array}{l}-12.514 \\
(2011 \mathrm{M} 04)^{* * *}\end{array}$ \\
\hline MPI & -1.878 & $0.195^{* *}$ & $\begin{array}{l}-3.668 \\
(2009 \mathrm{M} 04)^{* * *}\end{array}$ & $-12.587^{* * *}$ & 0.084 & $\begin{array}{l}-13.220^{* * *} \\
(2011 \mathrm{M} 03)\end{array}$ \\
\hline
\end{tabular}

$* * * * *$, and $*$ denote statistically significant at $1 \%, 5 \%$, and $10 \%$ levels, respectively

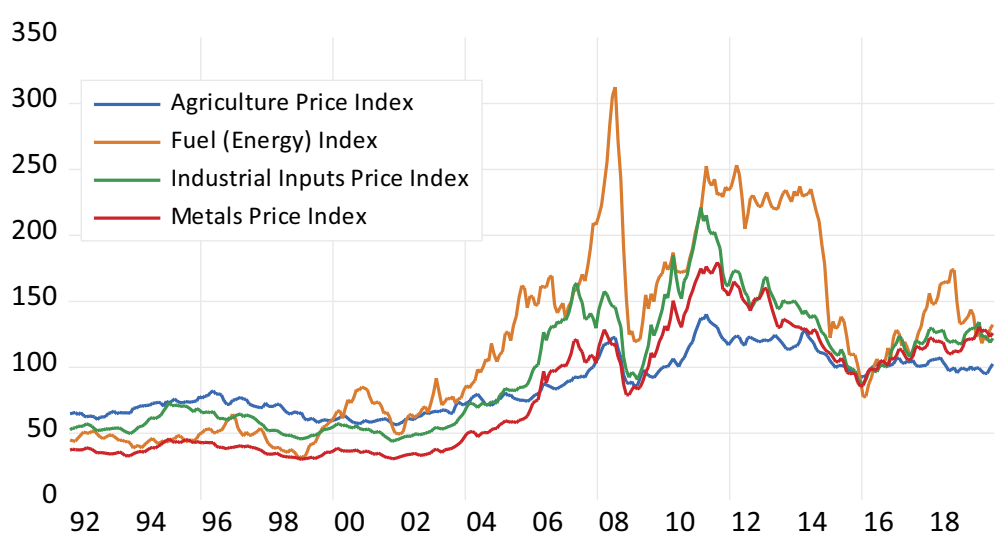

Fig. 1 Commodity and energy price indexes. Source: International Monetary Fund

Index (API), Industry Input Price Index (IPI), and Metal Price Index (MPI) time series variables. The results of these tests are reported in Table 2, with the model including both constant and constant and trend. As can be clearly seen in Table 2, the null hypothesis that the EPI time series variable has a unit root cannot be rejected at level, but at the first difference, the variable is stationary. In other words, the order of integration of EPI is one. This situation does not differ for the API, IPI, and MPI time series variables.

The unit root test of Cavaliere et al. (2011) is also employed to capture the integration order for the variables of EPI, API, IPI, and MPI. This test "allows for a possible structural break and non-stationary volatility, where the volatility includes both 
Table 3 Results of the test for unit roots in the presence of a possible break in trend and non-stationary volatility

\begin{tabular}{lcccccccc}
\hline & MZa & MZa c.v & MSB & MSB c.v & MZt & MZt c.v & t(taubar) & c.v \\
\hline \multicolumn{2}{l}{ Panel A: Unit-root tests in levels } \\
EPI & -12.790 & -23.366 & 0.192 & 0.145 & -2.453 & -3.399 & -2.408 & -3.505 \\
API & -10.458 & -19.552 & 0.215 & 0.159 & -2.246 & -3.106 & -2.236 & -3.182 \\
IPI & -7.812 & -22.709 & 0.249 & 0.146 & -1.948 & -3.364 & -1.922 & -3.466 \\
MPI & -5.522 & -21.920 & 0.300 & 0.150 & -1.658 & -3.289 & -1.642 & -3.384 \\
Panel B: Unit-root test in first differences & & & & & & \\
EPI & -123.572 & -25.857 & 0.064 & 0.136 & -7.859 & -3.508 & -9.153 & -3.352 \\
API & -129.303 & -24.170 & 0.062 & 0.142 & -8.035 & -3.443 & -9.592 & -2.936 \\
IPI & -41.975 & -26.526 & 0.109 & 0.134 & -3.577 & -3.615 & -4.257 & -3.492 \\
MPI & -22.224 & -24.787 & 0.150 & 0.141 & -3.324 & -3.513 & -3.434 & -3.293 \\
\hline
\end{tabular}

c.v. represents critical value



Fig. 2 Wavelet power spectrum for energy price index

single and multiple abrupt breaks in variance, polynomially trending volatility, piecewise trending volatility, and smooth transition variance breaks" (Ghoshray 2019). The results of the test are presented in Table 3 and show that the time series variables have a unit root at the level. This is consistent with the traditional unit root test reported in Table 2. However, Table 3 also indicates that we cannot reject the null hypothesis that IPI and MPI have a unit root at the first difference, indicating that the order of integration of both IPI and MPI variables is two, while the integration of order of EPI and API is one. Since we observed that the integrated order of the time series variables is a combination of $\mathrm{I}(1)$ and $\mathrm{I}(2)$, we use the wavelet coherence, Toda-Yamamoto, and gradual shift causality approaches to explore the causal linkage between EPI, API, IPI, and MPI. 


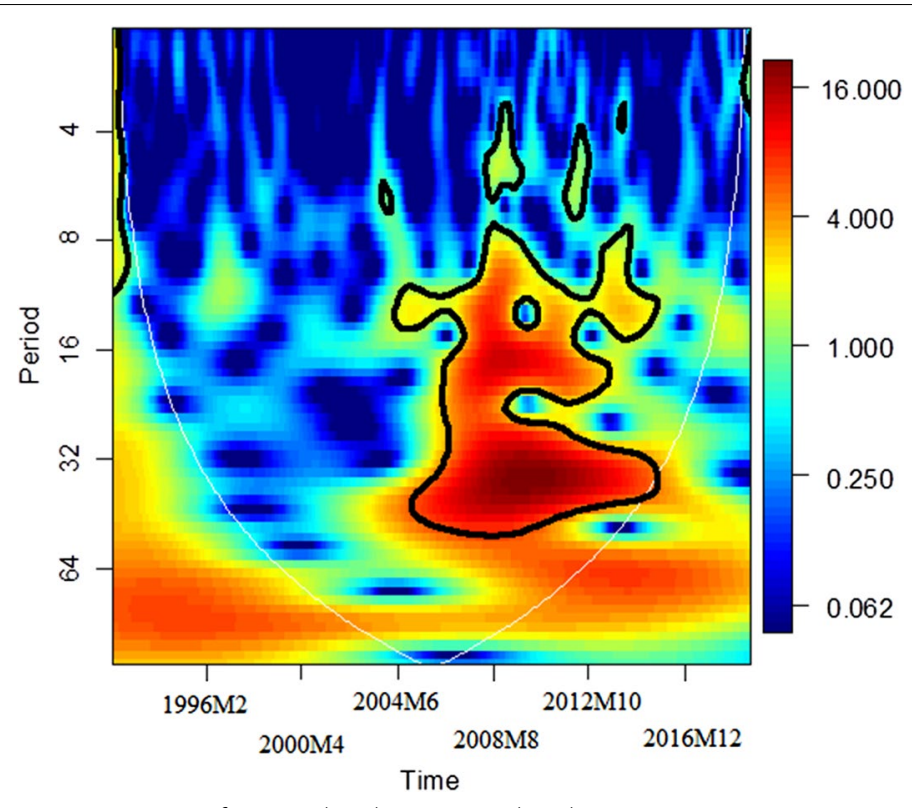

Fig. 3 Wavelet power spectrum for agricultural raw materials index

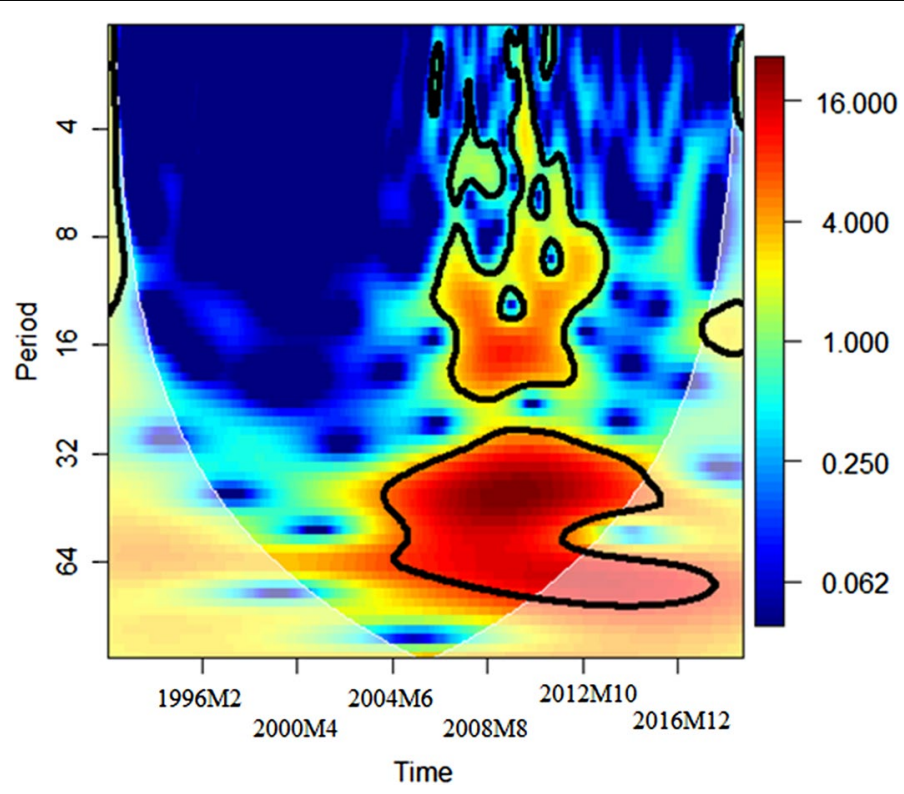

Fig. 4 Wavelet power spectrum for industry input price index

To gather information about the behaviour of the EPI, API, IPI, and MPI variables as well as the co-movement between the EPI and the API, IPI, and MPI variables, the wavelet approach is applied in this research. Figures 2, 3, 4, and 5 present the wavelet power spectrum for the EPI, API, IPI, and MPI variables, respectively. The energy price index variable appears to show significant volatility at low and medium frequencies between 2005 and 2015, as seen in Fig. 2. The behaviours of the Agricultural Raw Materials Price 


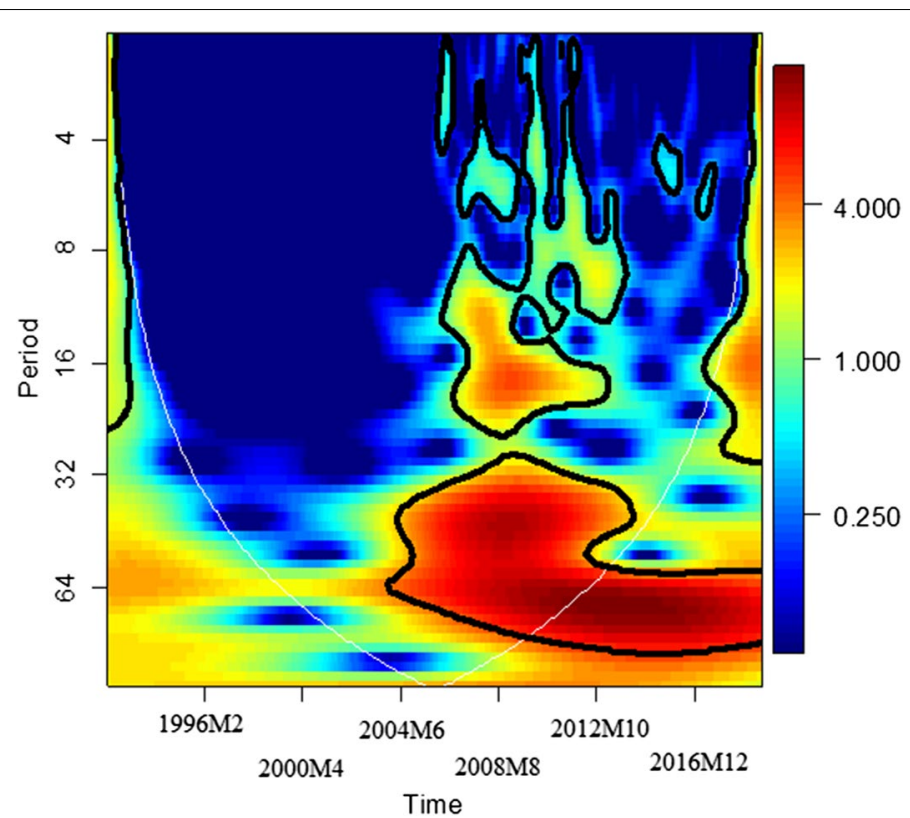

Fig. 5 Wavelet power spectrum for metal price index

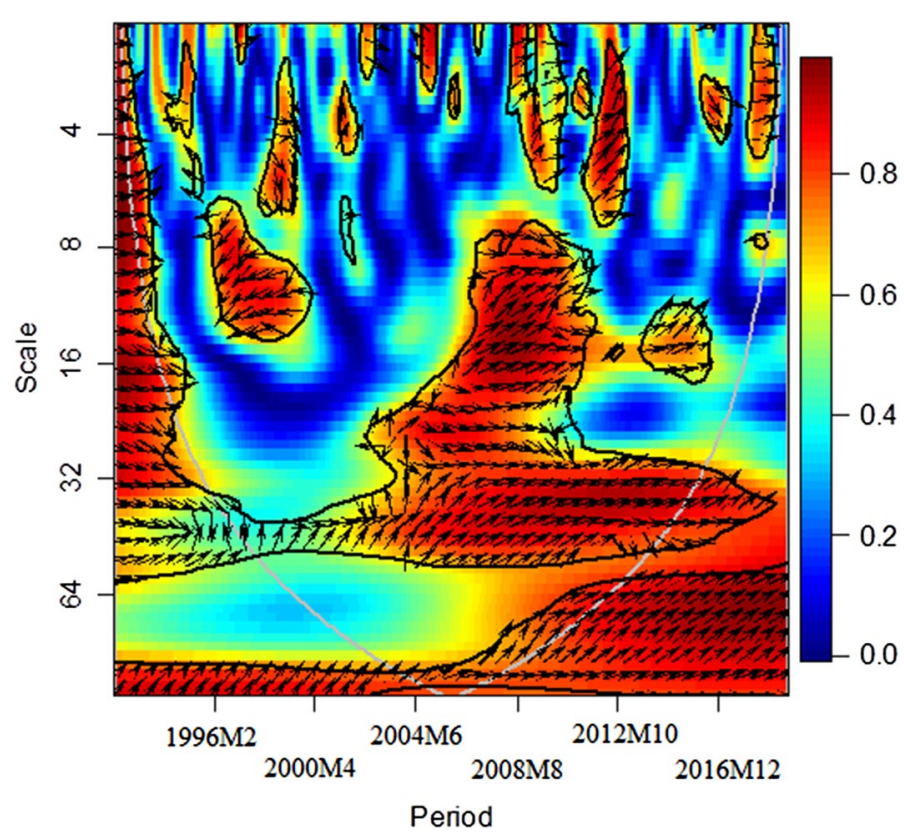

Fig. 6 Wavelet coherence between energy price index and agricultural raw materials index

Index, Industry Input Price Index, and Metal Price Index are not very different to the behaviour of the energy price index. In other words, the time series variable we use in this study was volatile between 2005 and 2015, but at different scales.

Consistent with the aim and innovation of our study, the wavelet coherence approach is applied to capture the causal relationship between the EPI and the API, 


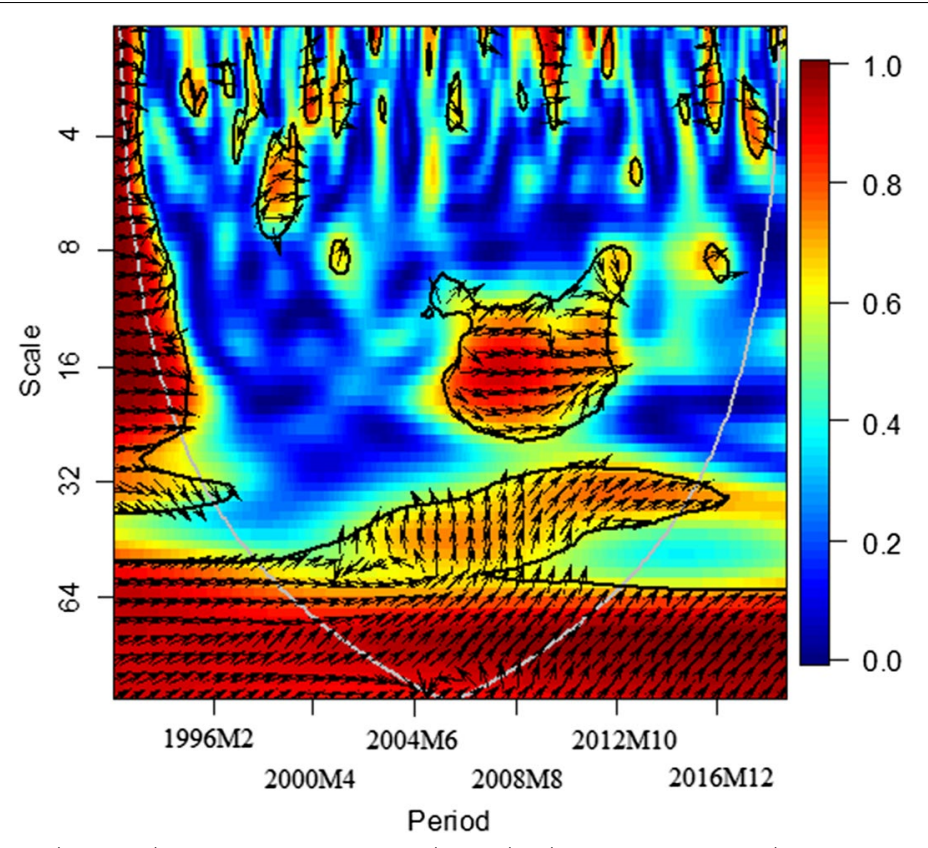

Fig. 7 Wavelet coherence between energy price index and industry input price index

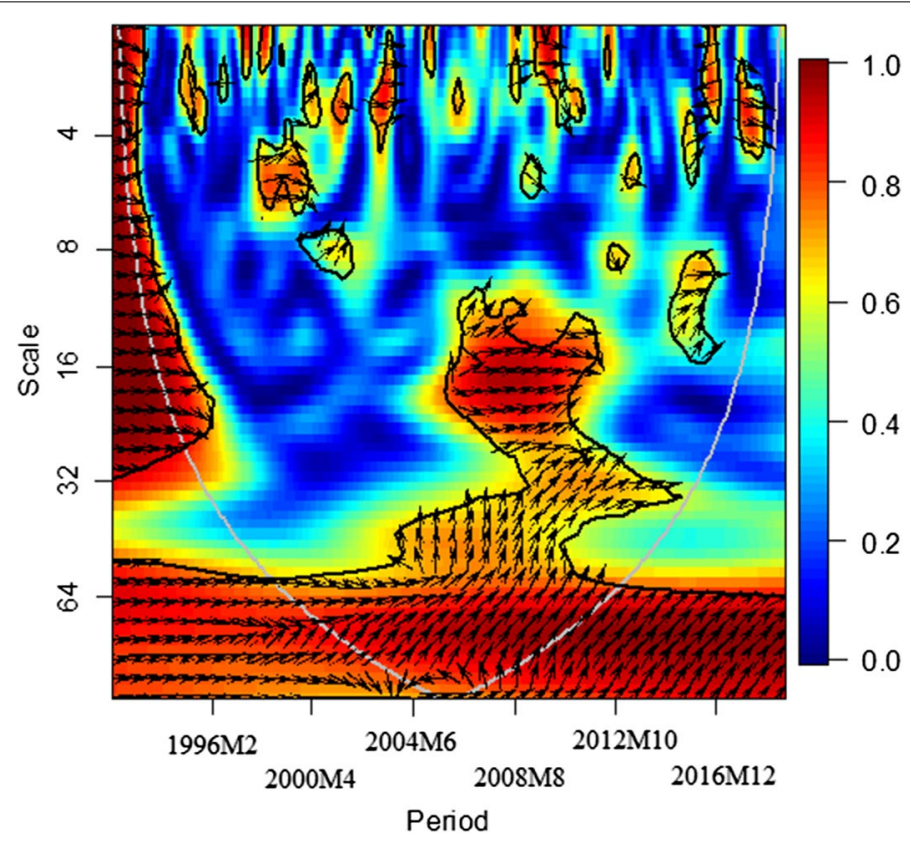

Fig. 8 Wavelet coherence between energy price index and metal price index

IPI, and MPI variables in the global market. The outcomes are reported in Figs. 6, 7, and 8. Figure 6 demonstrates wavelet coherence between the Energy Price Index and Agricultural Raw Materials Price Index. As can be seen in the figure, from scales 4 to 16, down and left-down arrows are obtained between 1996 and 2000, indicating 
that in the medium term, the energy price index significantly caused the Agricultural Raw Materials Price Index in the global market. However, the direction of the causality changes between 2004 and 2015 at different frequencies, since the arrows mostly point right-up, implying that the Agricultural Raw Materials Price Index is an important predictor of the energy price index for the period between 2004 and 2015.

The time-frequency dependency between the Energy Price Index and Industry Input Price Index is reported in Fig. 7. At high frequency over the selected time period, the arrows point right at the thick black shape, which implies that the variables are in phase. Between 2005 and 2012, in the medium term, there is a positive correlation between the Energy Price Index and Industry Input Price Index. However, in the long run, the Industry Input Price Index significantly leads changes in the energy price index in the global market. Figure 8 also reports consistent results with those in Fig. 7 for the Metal Price Index, since causality is observed in the long run from the Metal Price Index to the energy price index, indicating that the Metal Price Index is an important predictor of the energy price index. However, this conflicts with some findings in the empirical literature, such as Nazlioğlu et al. (2013), Wang et al. (2014), Avalos (2014), and Pal and Mitra (2017), who argue that in the post-crisis period of 2008, there is an even stronger link between energy prices and other commodity prices, which are led by energy prices. Baumeister and Kilian (2016) provided a detailed explanation of the case in which other commodity prices may have driven the oil prices. They argued that the oil price increase between 2003 and 2008 was due to a series of small demand shocks, which came from the unexpected growth of the global economy, particularly from emerging Asian markets. For example, additional demand for inputs increased the demand for oil, which caused the price of WTI to increase from 28 to 134 USD per barrel. In February 2009, the oil price falls back to 39 USD per barrel with increased global uncertainty resulting from the 2006-2008 global financial crisis. This was the case for all the commodity prices until the first half of 2008, with the expectation of a deep recession. ${ }^{1}$ In 2009, as a result of the relatively stable consumption component of world GDP, oil prices stabilized at around 100 USD per barrel, and non-energy commodity prices stabilized as well.

Another remarkable event in 2008 was the beginning of the use of unconventional monetary policy tools (also known as quantitative easing) to tackle the zero-lowerbound interest rate problem and reverse the effects of the 2006-2008 global financial crisis. The first episode of QE in the US started on 25 November 2008, and ended on 29 October 2014. Other major central banks (ECBS, BoJ, and BoE) followed similar liquidity strategies. This common liquidity strategy had a remarkable positive impact on the industrial production and growth rates of emerging markets. Baffes and Savescu (2014) explained the role of low-interest rates and unconventional monetary policy on metal prices, claiming that this increased the prices of agricultural commodities, metals, and industrial inputs. This, in turn, caused energy prices to increase.

Therefore, in such a volatile period, two demand shocks, i.e., the Asian growth effect and quantitative easing, had a positive impact on the growth of emerging economies, with a growing demand for industrial inputs, agricultural commodities, and metals,

${ }^{1}$ For example, for metal prices, see Rosen (2014); Hamilton (2009) also provides an extensive discussion on the run-up of oil prices in 2007-08. 
Table 4 Causality tests

\begin{tabular}{lrl}
\hline Direction of causality & MWALT & Prob \\
\hline Toda-Yamamoto causality & 17.127 & $0.000^{* * *}$ \\
$\mathrm{API} \rightarrow \mathrm{EPI}$ & 1.204 & 0.547 \\
$\mathrm{EPI} \rightarrow \mathrm{API}$ & 8.215 & $0.016^{* *}$ \\
$\mathrm{IPI} \rightarrow \mathrm{EPI}$ & 3.467 & 0.176 \\
$\mathrm{EPI} \rightarrow \mathrm{PI}$ & 8.891 & $0.031^{* *}$ \\
$\mathrm{MPI} \rightarrow \mathrm{EPI}$ & 2.744 & 0.432 \\
$\mathrm{EPI} \rightarrow \mathrm{MPI}$ & $\mathrm{F}$-stat & Prob \\
\hline & & \\
\hline $\mathrm{Gradual}$ shift causality & 17.303 & $0.000^{* * *}$ \\
$\mathrm{API} \rightarrow \mathrm{EPI}$ & 1.331 & 0.513 \\
$\mathrm{EPI} \rightarrow \mathrm{API}$ & 8.451 & $0.014^{* *}$ \\
$\mathrm{PI} \rightarrow \mathrm{EPI}$ & 3.558 & 0.168 \\
$\mathrm{EPI} \rightarrow \mathrm{PI}$ & 9.292 & $0.025^{* *}$ \\
$\mathrm{MPI} \rightarrow \mathrm{EPI}$ & 2.882 & 0.410 \\
$\mathrm{EPI} \rightarrow \mathrm{MPI}$ &
\end{tabular}

$\rightarrow$ indicates the direction of causality. The optimal lag is selected using AIC

***, ${ }^{* *}$, and ${ }^{*}$ denote statistically significant at $1 \%, 5 \%$, and $10 \%$ levels, respectively

with increasing prices. Papiez and Smiech (2012) stated that these price increases must cause a reaction in the energy prices. Our findings reveal that the prices of agricultural commodities, metals, and industrial inputs led to energy prices between 2005 and 2012. Once global conditions started to converge back to normal, such as with monetary tightening starting from 2013, the direction of causality from energy to an agricultural commodity, metal, and industrial input prices switched back, and energy prices started to cause the other prices.

To investigate the time domain causal relationship between commodity price indexes, i.e., the Agricultural Raw Materials Price Index, Industry Input Price Index, Metal Price Index, and Energy Price Index, for the period 1992M01 to 2019M12, the Toda-Yamamoto and gradual shift causality approaches are applied. Table 3 reports the outcomes of these tests. According to the Toda-Yamamoto causality results, the null hypothesis that the Agricultural Raw Materials Price Index does not cause the Energy Price Index can be rejected at the 5\% significance level, implying that the Agricultural Raw Materials Price Index is an important predictor for the Energy Price Index. However, we failed to capture a reverse causality from the Energy Price Index to the Agricultural Raw Materials Price Index. Consistent with the outcome of the wavelet coherence approach, Table 4 reports that the Industry Input Price Index and Metal Price Index are important predictors for the Energy Price Index. It is remarkable that the Toda-Yamamoto causality test is assumed not to have structural breaks among the series based on the assumption that the intercept parameters are constant over time. According to Gokmenoglu et al. (2019; p. 659), "the Fourier Toda-Yamamoto causality test is applied to take possible structural breaks into account. The test can be applied without conducting a preliminary investigation on the number and form of these breaks in the series." Although the methodology of the gradual shift causality test differs from that of the Toda-Yamamoto causality test, the 
outcomes of the gradual shift causality test verify the robustness of the unidirectional causality running from the commodity price indexes to the Energy Price Index in the presence of structural breaks.

\section{Conclusion}

The present study explores the time-dependency of commodity price indexes (the Agricultural Raw Materials Price Index, Industry Input Price Index, and Metal Price Index) and the Energy Price Index in the global market using wavelet coherence, the Toda Yamamoto causality test, and the gradual shift causality test over the period 1992M1 to 2019M12. The use of the wavelet approach allows the present study to (1) capture the volatility periods of the commodity price indexes and Energy Price Index; and (2) investigate the long- and short-run causal linkages between the commodity price indexes and the Energy Price Index, since the approach combines both time and frequency domain causalities. The findings from partial wavelet coherence reveal that (1) there was significant volatility in the Agricultural Raw Materials Price Index, Industry Input Price Index, Metal Price Index, and Energy Price Index between 2004 and 2014 at different frequencies; and (2) the commodity price indexes significantly caused the Energy Price Index at different time periods and frequencies, meaning that they are important predictors for the Energy Price Index. It is important to mention that the outcomes of the Toda Yamamoto causality and gradual shift causality tests are in line with the outcome of partial wavelet coherence. Our findings give support to the findings of Baumeister and Killian (2016), i.e., that the price indexes of industrial raw materials, metals, food, and energy respond to fluctuations in the global business cycle in the long run. Our findings are also in line with Papiez and Smiech (2012), who found evidence of simultaneous dependencies between the prices of energy and other commodities. Understanding the evolution of commodity prices is important in assessing macroeconomic performance. Producers, traders, investors, consumers, and policymakers are key stakeholders who have a significant interest in understanding the price evolution of energy and non-energy commodities. From the policymakers' perspective, there are some serious challenges ahead, since the energy industry is expected to experience dramatic changes in the near future due to the heavy pressures of climate change. This may make it even more difficult to understand the price formation and movements in energy markets. This transformation may further weaken the links between energy and non-energy commodities. Climate change risk and its impact on the price formation of energy and non-energy commodities seem to be one of the main areas of future research.

\section{Acknowledgements}

Not applicable.

Authors' contributions

DK and Hasan Gungor designed the experiment and collect the dataset. The introduction and literature review sections are written by HG. DK constructed the methodology section and empirical outcomes in the study. HG contributed to the interpretation of the outcomes. All the authors read and approved the final manuscript.

\section{Funding}

We also confirmed that this research did not receive any specific grant from funding agencies in the public, commercial, or not-for-profit sectors. 


\section{Competing interests}

The authors declare no competing interests.

\section{Author details}

${ }^{1}$ Department of Banking and Finance, Faculty of Economic and Administrative Sciences, European University of Lefke, Lefke, Northern Cyprus, TR-10, Mersin, Turkey. ${ }^{2}$ Department of Economics, Eastern Mediterranean University, Famagusta, North Cyprus, Turkey

Received: 6 October 2020 Accepted: 24 February 2021

Published online: 03 March 2021

\section{References}

Adebayo TS (2020) Revisiting the EKC hypothesis in an emerging market: an application of ARDL-based bounds and wavelet coherence approaches. SN Appl Sci 2(12):1-15

Adebayo TS, Beton Kalmaz D (2020) Ongoing debate between foreign aid and economic growth in Nigeria: a wavelet analysis. Soc Sci Q 101(5):2032-2051

Adebayo TS, Odugbesan JA (2020) Modeling $\mathrm{CO}_{2}$ emissions in South Africa: empirical evidence from ARDL based bounds and wavelet coherence techniques. Environ Sci Pollut Res 2020:1-13

Alekhina V, Yoshino N (2019) Exogeneity of world oil prices to the Russian Federation's economy and monetary policy. Eur Econ Rev 9(4):531-555

Alola AA, Kirikkaleli D (2020) Global evidence of time-frequency dependency of temperature and environmental quality from a wavelet coherence approach. Air Qual Atmos Health 2020:1-9

Avalos F (2014) Do oil prices drive food prices? The tale of a structural break. J Int Money Finance 42:253-271

Baffes J, Savescu C (2014) Monetary conditions and metal prices. Appl Econ Lett 21(7):447-452

Balcilar M, Hammoudeh S, Asaba NAF (2015) A regime-dependent assessment of the information transmission dynamics between oil prices, precious metal prices and exchange rates. Int Rev Econ Finance 40:72-89

Baumeister C, Kilian L (2016) Forty years of oil price fluctuations: why the price of oil may still surprise us. J Econ Perspect 30(1):139-160

Cavaliere G, Harvey DI, Leybourne SJ, Taylor AR (2011) Testing for unit roots in the presence of a possible break in trend and nonstationary volatility. Econ Theory 27:957-991

Chao X, Kou G, Peng Y, Viedma EH (2020) Large-scale group decision-making with non-cooperative behaviors and heterogeneous preferences: an application in financial inclusion. Eur J Oper Res 288:271-293

Chaudhuri K (2001) Long-run prices of primary commodities and oil prices. Appl Econ 33(4):531-538

Coronado S, Rojas O (2016) A study of co-movements between oil price, stock index and exchange rate under a crossbicorrelation perspective: the case of Mexico. arXiv:1602.03271

Cunado J, Jo S, de Gracia FP (2015) Macroeconomic impacts of oil price shocks in Asian economies. Energy Policy 86:867-879

de Nicola F, De Pace P, Hernandez MA (2016) Co-movement of major energy, agricultural, and food commodity price returns: a time-series assessment. Energy Econ 57:28-41

Demir E, Bilgin MH, Karabulut G et al (2020) The relationship between cryptocurrencies and COVID-19 pandemic. Eur Econ Rev 10:349-360

Esmaeili A, Shokoohi Z (2011) Assessing the effect of oil price on world food prices: application of principal component analysis. Energy Policy 39(2):1022-1025

Farzanegan MR, Markwardt G (2009) The effects of oil price shocks on the Iranian economy. Energy Econ 31(1):134-151

Fowowe B (2016) Do oil prices drive agricultural commodity prices? Evidence from South Africa. Energy 104:149-157

Ghoshray A (2019) Are shocks transitory or permanent? An inquiry into agricultural commodity prices. J Agric Econ 70(1):26-43

Goupillaud P, Grossmann A, Morlet J (1984) Cycle-octave and related transforms in seismic signal analysis. Geoexploration 23(1):85-102

Granger CW (1969) Investigating causal relations by econometric models and cross-spectral methods. Econ J Econ Soc 27:424-438

Grinsted A, Moore JC, Jevrejeva S (2004) Application of the cross wavelet transform and wavelet coherence to geophysical time series. Nonlinear Process Geophys 11:561-566

Jain A, Ghosh S (2013) Dynamics of global oil prices, exchange rate and precious metal prices in India. Resour Policy 38(1):88-93

Ji Q, Fan Y (2012) How does oil price volatility affect non-energy commodity markets? Appl Energy 89(1):273-280

Kang SH, Mclver R, Yoon SM (2017) Dynamic spillover effects among crude oil, precious metal, and agricultural commodity futures markets. Energy Econ 62:19-32

Kapusuzoglu A, Ulusoy MK (2015) The interactions between agricultural commodity and oil prices: an empirical analysis. Agric Econ 61(9):410-421

Karabulut G, Bilgin MH, Doker AC (2020) The relationship between commodity prices and world trade uncertainty. Econ Anal Policy 66:276-281

Kirikkaleli D (2019) Time-frequency dependency of financial risk and economic risk: evidence from Greece. J Econ Struct 8(1):37

Kirikkaleli D (2020) Does political risk matter for economic and financial risks in Venezuela? J Econ Struct 9(1):3

Kirikkaleli D (2021) Analyses of wavelet coherence: financial risk and economic risk in China. J Financ Econ Policy 66:101641

Klotz P, Lin TC, Hsu SH (2014) Global commodity prices, economic activity and monetary policy: the relevance of China. Resour Policy 42:1-9 
Koirala KH, Mishra AK, D'Antoni JM, Mehlhorn JE (2015) Energy prices and agricultural commodity prices: testing correlation using copulas method. Energy 81:430-436

Kou G, Peng Y, Wang G (2014) Evaluation of clustering algorithms for financial risk analysis using MCDM methods. Inf Sci 275:1-12

Kou G, Xu Y, Peng Y, Shen F, Chen Y, Chang K, Kou S (2020) Bankruptcy prediction for SMEs using transactional data and two-stage multiobjective feature selection. Decis Support Syst 140:113429

Kristoufek L (2015) What are the main drivers of the Bitcoin price? Evidence from wavelet coherence analysis. PLoS ONE 10(4):e0123923

Lucotte Y (2016) Co-movements between crude oil and food prices: a post-commodity boom perspective. Econ Lett $147: 142-147$

Mensi W, Beljid M, Boubaker A, Managi S (2013) Correlations and volatility spillovers across commodity and stock markets: linking energies, food, and gold. Econ Model 32:15-22

Morana C (2017) Macroeconomic and financial effects of oil price shocks: evidence for the euro area. Econ Model 64:82-96

Nazlioglu S, Erdem C, Soytas U (2013) Volatility spillover between oil and agricultural commodity markets. Energy Econ 36:658-665

Nazlioglu S, Gormus NA, Soytas U (2016) Oil prices and real estate investment trusts (REITs): gradual-shift causality and volatility transmission analysis. Energy Econ 60:168-175

Nazlioglu S, Soytas U (2011) World oil prices and agricultural commodity prices: evidence from an emerging market. Energy Econ 33(3):488-496

Nazlioglu S, Soytas U (2012) Oil price, agricultural commodity prices, and the dollar: a panel cointegration and causality analysis. EnergyEcono 34(4):1098-1104

Orhan A, Kirikkaleli D, Ayhan F (2019) Analysis of wavelet coherence: service sector index and economic growth in an emerging market. Sustainability 11(23):6684

Pal D, Mitra SK (2017) Time-frequency contained co-movement of crude oil and world food prices: a wavelet-based analysis. Energy Econ 62:230-239

Rafiq S, Bloch H (2016) Explaining commodity prices through asymmetric oil shocks: evidence from nonlinear models. Resour Policy 50:34-48

Reboredo JC (2012) Do food and oil prices co-move? Energy policy 49:456-467

Sari R, Hammoudeh S, Soytas U (2010) Dynamics of oil price, precious metal prices, and exchange rate. Energy Econ 32(2):351-362

Tang W, Wu L, Zhang Z (2010) Oil price shocks and their short-and long-term effects on the Chinese economy. Energy Econ 32:S3-14

Torrence C, Compo GP (1998) A practical guide to wavelet analysis. Bull Am Meteor Soc 79(1):61-78

Wang Y, Wu C, Yang L (2014) Oil price shocks and agricultural commodity prices. Energy Econ 44:22-35

Wang YS, Chueh YL (2013) Dynamic transmission effects between the interest rate, the US dollar, and gold and crude oil prices. Econ Model 30:792-798

Yu TH, Bessler DA, Fuller SW (2006) Cointegration and causality analysis of world vegetable oil and crude oil prices. Conf Paper. https://doi.org/10.22004/ag.econ.21439

Zhang L, Li Z, Kirikkaleli D, Adebayo TS, Adeshola I, Akinsola GD (2021) Modeling $\mathrm{CO}_{2}$ emissions in Malaysia: an application of Maki cointegration and wavelet coherence tests. Environ Sci Pollut Res 1:1-15

Zhang Q, Reed MR (2008) Examining the impact of the world crude oil price on China's agricultural commodity prices: the case of corn, soybean, and pork. MR Reed. https://doi.org/10.22004/ag.econ.6797

\section{Publisher's Note}

Springer Nature remains neutral with regard to jurisdictional claims in published maps and institutional affiliations.

\section{Submit your manuscript to a SpringerOpen ${ }^{\circ}$ journal and benefit from:}

- Convenient online submission

- Rigorous peer review

- Open access: articles freely available online

- High visibility within the field

Retaining the copyright to your article

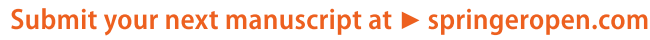

